\title{
Volatile organic compounds (VOC) variation in Croton floribundus (L.) Spreng. related to environmental conditions and ozone concentration in an urban forest of the city of São Paulo, São Paulo State, Brazil
}

\author{
Vanessa Palermo Bolsoni ${ }^{1}$, Débora Pinheiro de Oliveira ${ }^{1}$ and Giselle da Silva Pedrosa ${ }^{2}$, and \\ (iD)
}

Received: 12.09.2017; accepted: 8.03.2018

\begin{abstract}
Volatile organic compounds (VOC) variation in Croton floribundus (L.) Spreng. related to environmental conditions and ozone concentration in an urban forest of the city of São Paulo, São Paulo State, Brazil). Volatile organic compounds (VOC) are emitted by vegetation in response to different kinds of stress, such as herbivory, environmental conditions and air pollutants. The aim of this study was to identify the VOC emitted by seedlings of Croton floribundus (L.) Spreng. exposed to a polluted environment and analyze the relationship among classes of compounds emitted, ozone levels and changes in climate conditions. Two exposures were carried out, one in winter (June to August 2012) and another in summer (January to April 2013), in the Parque Estadual das Fontes do Ipiranga, city of São Paulo, São Paulo State, Brazil. We identified 26 compounds that are grouped into oxygenates, aromatics, monoterpenes and sesquiterpenes. The emission of sesquiterpenes was inhibited in summer, while those of the oxygenated and aromatic compounds were induced. The emission of volatiles was correlated to ozone levels (AOT 40). Our results suggest that the levels of atmospheric ozone detected in the summer can increase the induction of oxygenates and reduce the emission of monoterpenes in C. floribundus plants. Keywords: abiotic factors, air pollutants, oxidative stress
\end{abstract}

RESUMO - (Variação dos compostos orgânicos voláteis (COV) de Croton floribundus (L.) Spreng. às condições ambientais e concentração de ozônio em floresta urbana de São Paulo, SP, Brasil). Os compostos orgânicos voláteis (COV) são emitidos pela vegetação em resposta ao estresse, incluindo fatores como herbivoria, condições ambientais e poluentes aéreos. Os objetivos deste trabalho foram identificar compostos orgânicos voláteis emitidos por plantas jovens de Croton floribundus (L.) Spreng. expostas em ambiente poluído e relacionar as classes dos compostos emitidos com os níveis de ozônio atmosférico e variações climáticas. Foram realizadas duas exposições em diferentes estações climáticas (inverno de 2012: junho a agosto e verão de 2013: janeiro a abril), no Parque Estadual das Fontes do Ipiranga, São Paulo, SP, Brasil. Foram identificados 26 compostos, agrupados em oxigenados, aromáticos, monoterpenos e sesquiterpenos. As emissões dos sesquiterpenos foram inibidas no verão, enquanto as dos oxigenados e aromáticos foram induzidas. Os voláteis foram relacionados com os níveis de ozônio (AOT 40). Os resultados sugerem que os níveis de ozônio atmosférico detectados no verão podem contribuir para aumentar a emissão dos compostos oxigenados e reduzir a emissão dos monoterpenos em plantas de C. floribundus.

Palavras-chave: estresse oxidativo, fatores abióticos, poluentes atmosféricos

\section{Introduction}

Volatile organic compounds (VOC) emitted by biogenic sources have a key role in the atmospheric chemistry and exceed those of anthropogenic origin in order of magnitude (Guenther 1997). Biogenic emissions comprise $90 \%$ of the organic compounds emitted annually and are considered as the major terrestrial source of carbon for the atmosphere (Niinemets et al. 2010).

Biogenic VOC are directly associated with climate change, because to some extent, they modify the global balance of atmospheric carbon (Fehsenfeld et al.1992). These VOCs induce photochemical processes in the atmosphere, forming products that feedback oxidant species such as ozone, and thus

1. Instituto de Botânica, Núcleo de Pesquisa em Ecologia, Av. Miguel Stéfano, no 3.687, 04301-902 São Paulo, SP, Brasil

2. Universidade Federal do ABC, Biotecnociência, Av. dos Estados, nº 5.001 - Bangú, Santo André - SP, 09210-58SP, Brasil

3. Corresponding author: souzasrd@gmail.com 
altering the equilibrium of methane and carbon monoxide $(\mathrm{CO})$ in the atmosphere, which leads to yet unmeasured environmental damages (Fehsenfeld et al. 1992, Guenther et al. 1995).

In urban regions where the ozone concentration can reach up to $200 \mathrm{ppb}$ and that have green fragmented areas in their surroundings, such as the city of São Paulo (Orlando et al. 2010), the contribution of biogenic VOC and other tropospheric oxidants to ozone formation can be significant.

It should be considered that VOC, in the presence of nitrogen oxides and solar radiation, form photochemical smog, which through a complex chain of reactions produces ozone $\left(\mathrm{O}_{3}\right)$, peroxyacetyl nitrate (PAN), hydrogen peroxide $\left(\mathrm{H}_{2} \mathrm{O}_{2}\right)$, aldehydes, and ketones, among others compounds (Krupa \& Manning 1988). Furthermore, VOCs can undergo photolysis and react with the ozone itself $\left(\mathrm{O}_{3}\right)$ and the radicals $\mathrm{OH}$ and $\mathrm{NO}_{3}$, reducing the concentrations of both compounds in the atmosphere (Sienfeld \& Pandis 1998). Therefore, the atmospheric concentrations of ozone and other air pollutants are sensitive to superficial VOC fluxes, which can lead to their either accumulation or reduction (Ciccioli 1993, Schirmer et al. 2010).

Ozone is one of the most aggressive pollutants for vegetation, attaining the cell via stomata and, once inside the stomatal complex, reaches the subestomatic cavity where it is soluble, and spreads through the intercellular spaces of the mesophyll by molecular diffusion (Cardoso-Gustavson et al. 2014). The plant responds to oxidative stress caused by ozone through physiological and biochemical changes that lead to the increase in VOC emission (Loreto \& Schnitzler 2010). This VOC increase prevents the entrance of more ozone into the leaf cell, since volatiles may react with ozone and degrade it even before reaching the leaf (Loreto \& Schnitzler 2010, Niinemets et al. 2010).

The mechanisms of VOC release by plants are still not well understood due to the lack of knowledge on factors that alter the metabolism of production of those compounds and their emission. It is well known that plants emit organic volatiles to defend themselves against biotic and abiotic factors, such as herbivores and air pollutants, respectively (Tingey et al. 1991, Arimura et al. 2009, Niinemets et al. 2010). In addition, several factors may alter the pattern of VOC emissions, such as water deficit, temperature, photoperiod, $\mathrm{CO}_{2}$ increase and air pollutants (Peñuelas et al. 1999, Loreto \& Velikova 2001, Baier et al. 2005). Thus, studies that analyze the rate of VOC emission from plants exposed to air pollution, especially to ozone, are important for determining which biogenic volatiles are predominant in urban areas impacted by air pollution, as well as for identifying which plant species are emitters of highly reactive volatiles to the atmosphere.

Although emissions by vegetation in the tropical regions are not well known, they might have an important role in the behavior of the atmosphere, since in these regions there is a wide diversity of plant species and a great vegetation complexity. Several plant species that emit significant amounts of monoterpenes and oxygenated compounds have been studied in some countries worldwide (Arey et al. 1991, Owen et al. 1998, Kesselmeier \& Staudt 1999) and some genera of these plants are present in the Ombrophilous Dense Florest of São Paulo, Brazil (Aragaki \& Mantovani 1998). However, studies assessing the VOC emission rate in Brazilian native species are rare, particularly in the case of species that are present in urban regions impacted by air pollution (Souza et al. 2002, Carvalho et al. 2005). Croton floribundus (L.) Spreng is a pioneer plant that belongs to the Family Euphorbiaceae, commonly known as "capixingui". This family has a wide distribution throughout Brazil (Ziroldo 2007) and can be found either as a tree, shrub, herb or climbing plant (LEME, 1994). Due to its high phenotypic plasticity, this family has been recommended for cultivation in parks and sub-forests in urban areas and for the restoration of degraded areas (Meira Júnior et al. 2015).

VOC are generally species-specific and may or may not contribute the increase in atmospheric ozone. Thus, to know the VOCs of plant species that are widely used in restoration can aid the selection of these species for cultivation in areas impacted by air pollutants. In this context, we aim at evaluating the emission of volatile organic compounds (VOCs) from leaves of $C$. floribundus seedlings exposed to the atmosphere of "Parque Estadual das Fontes do Ipiranga" (PEFI), in order to relate climatic conditions and ozone levels to the classes of VOC emitted.

\section{Materials and methods}

Seedlings of Croton floribundus purchased in the Bioflora nursery, Piracicaba, State of São Paulo, were transplanted to plastic pots containing a Plantimax (Eucatex) substrate-type + vermiculite (3:1). Plants 
were cultivated in a greenhouse with filtered air, free of gaseous and particulate pollutants at the "Instituto de Botânica", which is placed inside the "Parque Estadual das Fontes do Ipiranga" (PEFI), located in the southeast region of the Metropolitan Region of São Paulo.

Irrigation was maintained by capillarity with nylon strings immersed in water. After two weeks of acclimation, two treatments were carried out with a plot of plants containing 12 individuals: a) exposure to the PEFI environment and b) maintenance in a greenhouse with air free of pollutants. Two exposures of three months each were performed. The first exposure was during the winter of 2013 (JuneAugust), while the second one occurred during the summer of 2013/2014 (January-April).

The atmospheric ozone was measured throughout the exposure period with an ECOSOFT continuous monitor (model 60B). The medium concentration of ozone was $74 \mathrm{ppb}$ and $46 \mathrm{ppb}$ in winter and summer, respectively. The climatic conditions (temperature, radiation and relative humidity) during both exposures were monitored using a meteorological station located in the PEFI. In winter, mean values of temperature, radiation, and relative humidity were $17^{\circ} \mathrm{C}, 408 \mathrm{MJ} /$ $\mathrm{m}^{2}$ and $79 \%$, while in summer, $22^{\circ} \mathrm{C}, 513 \mathrm{MJ} / \mathrm{m}^{2}$ and $82 \%$, respectively (table 1 ).

Three individuals from each treatment were collected at 0, 38, 57 and 72 days of exposure. Leaves from each individual were maintained in Teflon bags with lateral openings to ensure gas exchange.

The volatiles were collected through cartridges, containing 100mg of Tenax TA adsorbent (Supelco, $60 / 80$ mesh), with one end fixed to the bag's opening and the other connected to a suction pump, in order to ensure the air flow through the cartridge. The flow of sampled air was maintained at $180 \mathrm{ml} / \mathrm{min}$ and the air was introduced into the bags at $1.2 \mathrm{~L} / \mathrm{min}$. The sampling period of volatiles was of $1 \mathrm{~h} 3 \mathrm{~min}$. The sampled volatiles were thermally deabsorved by a thermal deabsortion system (ATD650, Perkin Elmer) and analyzed by gas chromatography (Agilent 7890B) coupled to a mass spectrometer (Agilent 5977A). The Kovats' index (KI cal) was calculated from the time of retention of each sample to be posteriorly compared with reference values (KI) found in the literature.

Data were analyzed using one-way analysis of variance (ANOVA) and the means were compared between treatments with Tukey's test (statistical significance set at $p<0.05$ ) using the program IBM SPSS statistics v. 20. A principal component analysis was performed using the multivariate statistical software package PC-ORD v. 6.0 to explore if treatments are grouped according to the chemical compounds emitted.

\section{Results}

We identified 26 volatile compounds emitted by the leaves of Croton floribundus during winter and summer, which belong to four different chemical classes: 12 oxygenated (OX), seven aromatic (AR), three monoterpenes (MT) and four sesqueterpenes (ST), as shown in table 2 and figure 1 . Among them, the most abundant were the aldehyde E-Z 2-4 nonadienal, the ester methyl salicylate, the monoterpene geranyl acetone and the oxygenated sesquiterpene nerolidol, which belong to the classes OX, AR, MT and ST, respectively.

The percentage of emission of compounds was higher in the individuals exposed to the PEFI environment compared to the control. The number of OX and AR compounds detected was higher in winter, although the sum of the emission percentage of these compounds was higher in the summer. The most emitted OXs were methyl decanoate in winter and E-Z-nonadienol in summer. In the case of AR compounds, the main were methyl benzaldehyde in winter and methyl salicylate in summer. Among the terpenoids, the most abundant compounds in summer

Table 1. Mean temperature, radiation, relative humidity and hourly concentration of ozone during the exposure of Croton floribundus seedlings to the polluted atmosphere of the city of São Paulo, São Paulo State, Brazil, during the winter and summer.

\begin{tabular}{lcccccc}
\hline \multicolumn{2}{c}{ Winter } & \multicolumn{5}{c}{ Summer } \\
\hline Climatic conditions & June (2013) & July (2013) & August (2013) & December (2013) & January (2014) & February (2014) \\
\hline Temperature $\left({ }^{\circ} \mathrm{C}\right)$ & 17 & 16.4 & 17 & 23 & 21 & 22 \\
Radiation $\left(\mathrm{MJ} / \mathrm{m}^{2}\right)$ & 280 & 395 & 550 & 600 & 440 & 500 \\
Relative humidity $(\%)$ & 86 & 77 & 74 & 81 & 84 & 81 \\
Ozone (ppb) & 86 & 90 & 46 & 62 & 25 & 51 \\
\hline
\end{tabular}


and winter were geranyl acetone and nerolidol, and (Z) -3,7-dimethyl-2,6-octadiene and caryophyllene oxide, respectively (table 2 ).

The relationship between the sum of the ozone accumulation above $40 \mathrm{ppb}$ (AOT40) and the percentage of compounds emitted during summer at 38,57 and 72 days (figure 2), indicates a correlation between the AOT40 and the percentage of emission of OX and MT, which was positive for OX and negative for MT.
Principal component analysis (PCA) of the biological variables showed four groups (figure 3 ). Groups 1 and 2 corresponded to plants maintained in the PEFI environment and to the winter control, respectively, and were associated to the axes influenced by ST. Groups 3 and 4 corresponded to the plants kept in the environment and to the summer control, respectively, and were influenced by other classes of compounds.

Table 2. Mean of percent area of volatile organic compounds emitted by Croton floribundus during winter and summer. Calculated (cal KI) and reference (KI) values of Kovats retention index.

\begin{tabular}{|c|c|c|c|c|c|c|c|c|}
\hline & Winter & & & Summer & & & & \\
\hline Class & Compound & $\mathrm{IK}$ & IK cal & PEFI & Control & IK cal & PEFI & Control \\
\hline \multicolumn{9}{|c|}{ Oxygenated } \\
\hline & Nonan-2-one & 1091 & 1091.28 & 0.53 & 0.67 & - & - & - \\
\hline & Decanal & 1211 & 1211.76 & 0.32 & 0.51 & 1211.54 & 0.23 & 0.46 \\
\hline & (Z)-5-Hexadecenal & 1799 & 1799.55 & 0.32 & 0.26 & - & - & - \\
\hline & (Z)-2-Decenal & 1250 & - & - & - & 1250.65 & 2.31 & 2.32 \\
\hline & Methyl decanoate & 1326 & 1326.86 & 0.64 & 0.59 & - & - & - \\
\hline & Pentadecanal & 1687 & 1687.75 & 0.51 & 0.19 & - & - & - \\
\hline & Pentadecanoic acid & 1829 & 1820.43 & 0.5 & 0.33 & - & - & - \\
\hline & Nonadecanal & 2105 & 2105.01 & 0.37 & 0.33 & - & - & - \\
\hline & Octadecanoic acid & 2200 & 2200.18 & 0.47 & 0.385 & - & - & - \\
\hline & (E)-3-Octen-2-one & 1034 & - & - & - & 1034.70 & 4.07 & 3.21 \\
\hline & (E,Z)-2,4-Nonadienal & 1196 & - & - & - & 1196.75 & 11.67 & 11.27 \\
\hline & Nonanal & 1098 & 1098.6 & 0.55 & 0.65 & 1098.9 & 0.085 & 0.17 \\
\hline \multicolumn{9}{|c|}{ Aromatic } \\
\hline & (Z) -3-Hexenyl benzoate & 1252 & 1252.18 & 2.79 & 0.57 & - & - & - \\
\hline & (Z) -3-Hexenyl benzoate & 1570 & 1570.27 & 0.48 & 0.63 & - & - & - \\
\hline & Ethyl benzoate & 1170 & 1170.68 & 0.72 & 0.42 & - & - & - \\
\hline & Methyl salicylate & 1191 & 1191.13 & 0.63 & 0.30 & 1191.94 & 4.45 & 2.22 \\
\hline & Methyl benzyl formate & 1335 & 1335.56 & 0.57 & 0.57 & - & - & - \\
\hline & Methyl 3,4-dimethyl benzoate & 1353 & 1353.73 & 0.34 & 0.52 & - & - & - \\
\hline & $\begin{array}{l}\text { 2-Phenyl ethyl (E) -2-methyl-2- } \\
\text { butenoate }\end{array}$ & 1584 & 1584.64 & 0.58 & 0.53 & - & - & - \\
\hline \multicolumn{9}{|c|}{ Monoterpenes } \\
\hline & (Z) -3,7-Dimethyl-2,6-octadienal & 1235 & 1235.28 & 0.68 & 0.39 & - & - & - \\
\hline & 2,6-Dimethyl-2,7-octadien-6-ol & 1098 & 1098.67 & 0.55 & 0.65 & 1098.89 & 0.08 & 0.17 \\
\hline & $\begin{array}{l}\text { (E) -6,10-Dimethyl-5,9- } \\
\text { undecadien-2-one (geranyl } \\
\text { acetone) }\end{array}$ & 1453 & 1453.41 & 0.54 & 0.32 & 1453.66 & 1.08 & 2.16 \\
\hline \multicolumn{9}{|c|}{ Sesquiterpenes } \\
\hline & Alpha-cubebeno & 1351 & 1351.38 & 0.56 & 0.42 & 1351.73 & 0.46 & 0.93 \\
\hline & Beta-Gurjunene & 1423 & 1423.10 & 0.38 & 0.54 & - & - & - \\
\hline & Nerolidol & 1564 & 1564.02 & 0.54 & 0.44 & 1564.5 & 2.73 & 1.77 \\
\hline & Caryophyllene oxide & 1581 & 1581.91 & 0.70 & 0.49 & - & - & - \\
\hline
\end{tabular}




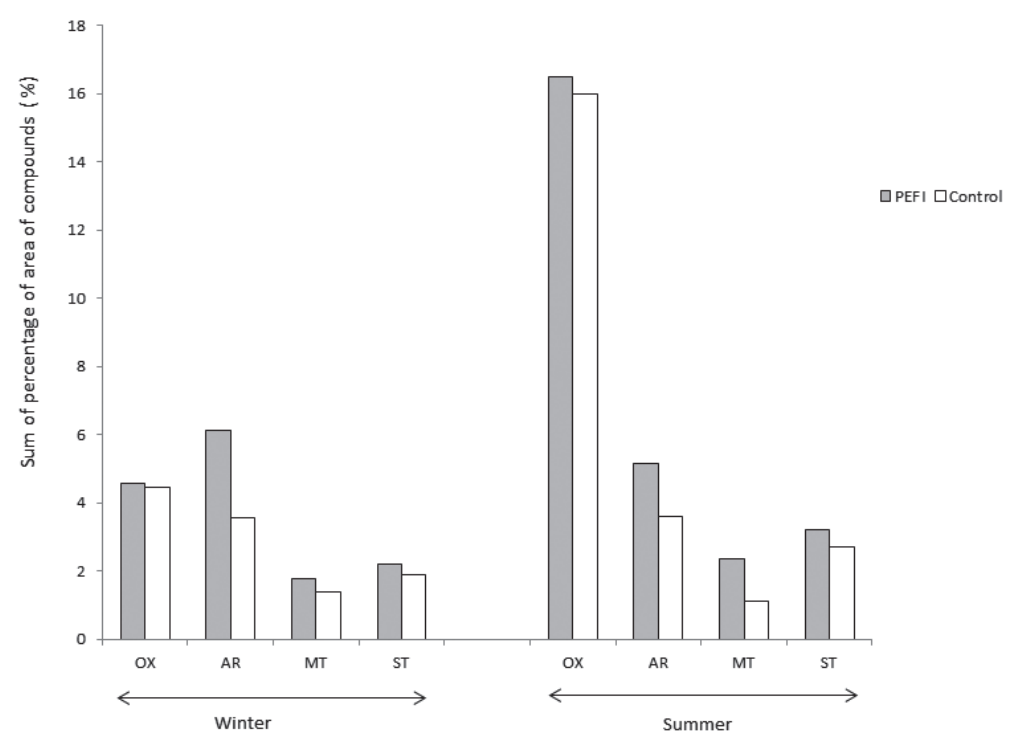

Figure 1. Sum of the percentages of the area of each class of volatile organic compounds emitted by Croton floribundus in winter and summer. PEFI: Parque Estadual das Fontes do Ipiranga. Control: Greenhouse. References: Oxygenates (OX), Aromatics (AR), Sesquiterpenes (ST) and monoterpenes (MT).

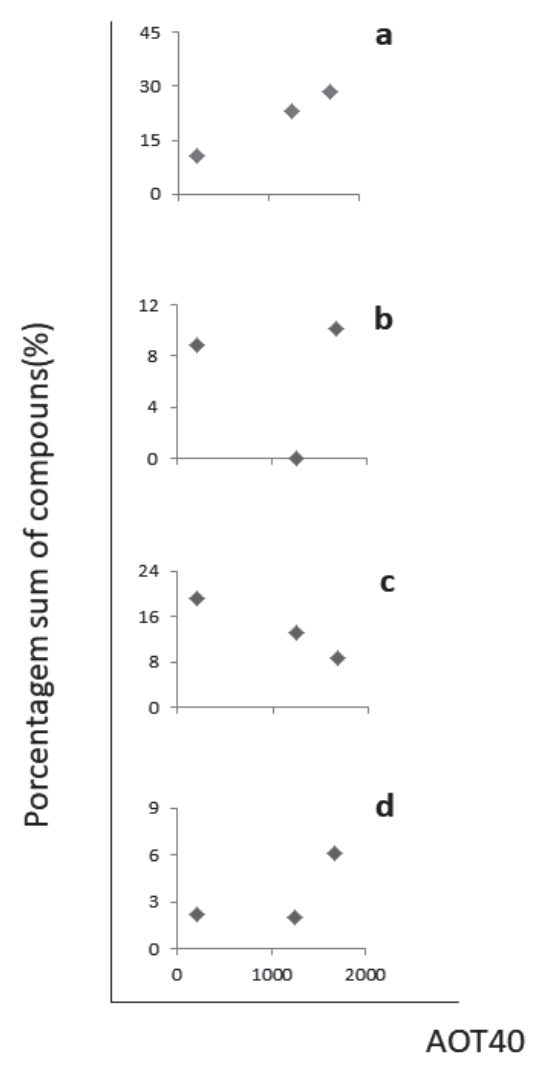

Figure 2. Relationship between the sum of the percentage of the area of oxygenates (a), aromatic (b), monoterpenes (c) and sesquiterpenes (d) emitted by Croton floribundus, and the sum of hourly values of ozone concentration above $40 \mathrm{ppb}$ (AOT40) in summer.

\section{Discussion}

The sum of the percentages of the area of each class of compounds showed that isoprenoids (MT and ST) were emitted more in summer than in winter and that there was a predominance of ST emission than of MT (figure 1). This variation in VOC emissions can be due to the increase in temperature during summer. According to Monson et al. (1992), the temperature influences the enzymatic activity responsible for the synthesis of many VOCs. Although little studied, the optimum temperature range for isoprenoid emission is generally between 30 and $40{ }^{\circ} \mathrm{C}$. The highest temperature reached in summer was $35^{\circ} \mathrm{C}$ while in winter was $28{ }^{\circ} \mathrm{C}$, indicating that the terpenoids emitted by $C$. floribundus might have been influenced by the local temperature. Our results are in agreement with Bartram et al. (2006), who found that some abiotic factors such as temperature and radiation positively influenced the ST production.

According to Loreto et al. (2006), MT emissions can be negatively influenced in environments with a temperature higher or equal to $40{ }^{\circ} \mathrm{C}$. In summer, control plants kept under greenhouse conditions with filtered air had a decrease in MT. Although greenhouses had good control conditions for air pollutants, they did not always provide appropriate refrigeration since often we registered higher temperatures than at the PEFI. They also have shown that ozone and temperature may act jointly to accelerate the induction of various VOCs. During our study period (2012-2013), there was a lower ozone concentration and 
a higher temperature in summer than in winter. The lower ozone levels found in summer can be partially due to the activity of a South Atlantic Convergence Zone, which increased rainfall throughout the State of São Paulo during this season, favoring cloudiness. This resulted in a less incidence of solar radiation and fewer exceedances of the air quality standard for ozone (CETESB 2012, 2013). On the contrary, in winter, drought and other meteorological conditions favored the formation of ozone, and thus caused the excess of the air quality standard for this pollutant during several days.

The emission of methyl salicylate (MeSA), which is produced under stress conditions, increased in the presence of ozone and high temperatures (Loreto \& Schnitzler 2010, Cardoso-Gustavson et al. 2014). Our results showed that in summer the percentage of MeSA was significantly different between control plants and those exposed to the polluted environment; in contrast, no significant differences were found in winter. This discrepancy between winter and summer MeSA emissions indicated that this aromatic compound, besides of being emitted in larger amounts during the summer when temperatures are higher, had its emission rate increased due to the conditions to which plants were exposed. The volatiles emitted by the plants in summer, such as geranil acetone and nerodiol, presented a high reactive capacity in the atmosphere and can contribute to the increase in ozone itself.

The aldehydes, aromatic compounds and isoprenoids identified in the present study have a high reactive potential with radicals and can contribute to the increase in the reactive capacity of the atmosphere, which can also result in ozone accumulation (Carvalho et al. 2005).

The sum of hourly values of ozone concentration in the environment above $40 \mathrm{ppb}$, defined as AOT40, was herein considered because it is the only ozone index for the protection of plant species that is regulated. Although this index is more appropriate for European species, it can be considered as the limit of exposition for tropical species (Boutsoukidis et al. 2012). On the other hand, the absence of a relationship between AOT40 and ST suggests that the ozone values reached during the study period did not induce the

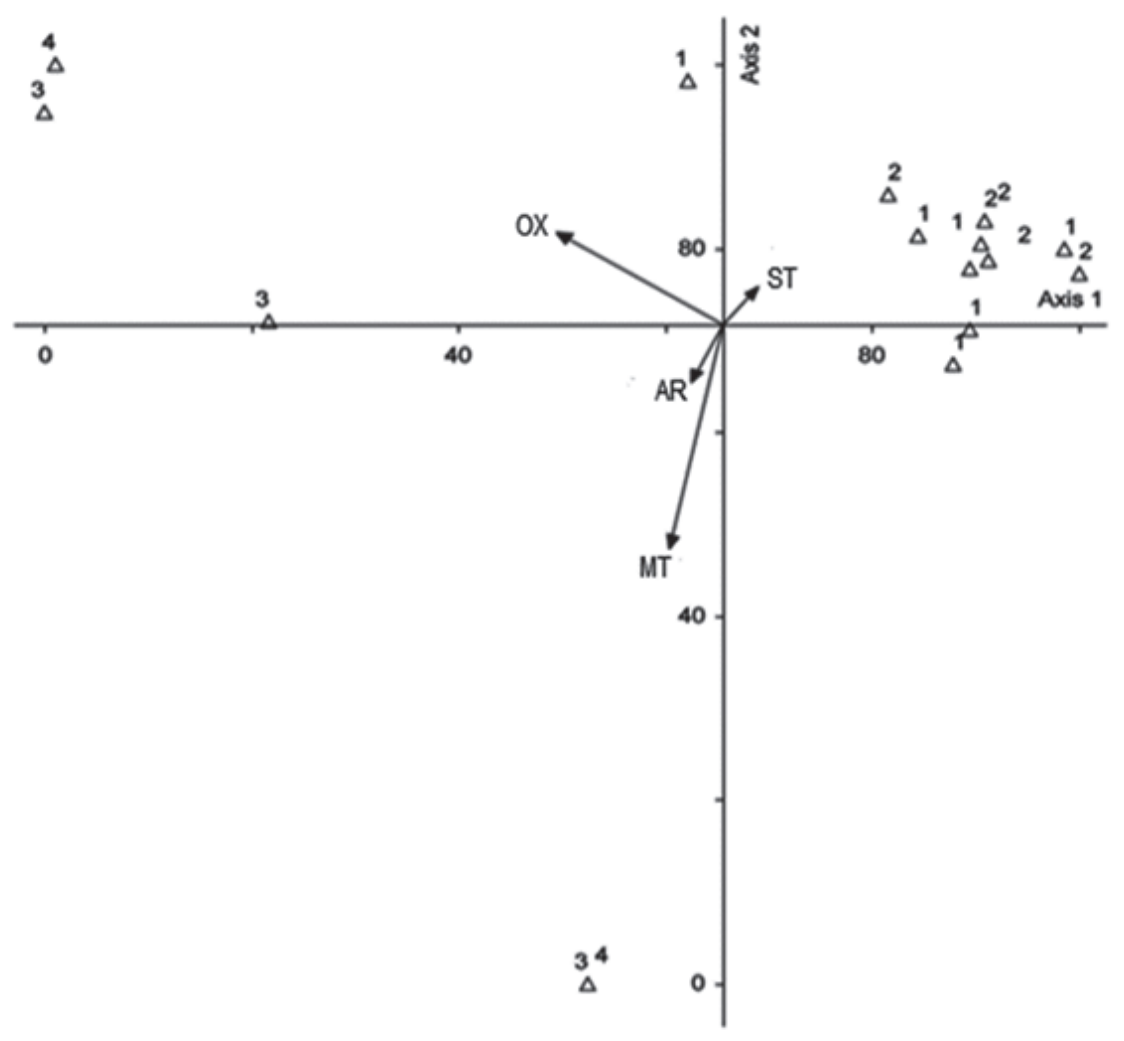

Figure 3. Principal components analysis (PCA) of the biological variables assessed in Croton floribundus during winter (1-environment of PEFI; 2-control) and summer (3-environment, 4 control). References: Oxygenates (OX), Aromatics (AR), Sesquiterpenes (ST) and Monoterpenes (MT). 
emission of these compounds. However, the emission of ST during winter was the variable that contributed most to differentiate winter from summer along the two axis, indicating that the emission of this class of compounds is closely related to climatic conditions.

\section{Conclusion}

Volatile oxygenated compounds and monoterpenes varied linearly with the increase in atmospheric ozone, indicating that urban pollution can be a factor of induction of biogenic compounds of high reactivity to the atmosphere. The sesquiterpene emission was more related to seasonal variation than to the concentration of atmospheric ozone. Experiments under controlled conditions need to be performed to corroborate the role of environmental conditions on volatile emission rates, and therefore establish the response limits of this species to ozone and temperature.

\section{Acknowledgments}

The authors would like to thank "Fundação de Amparo à Pesquisa do Estado de São Paulo" (FAPESP 12/11663-8, FAPESP 2016/25109-3) for the financial support. Vanessa Bolsoni and Débora Pinheiro de Oliveira thank CNPq program for the masters scholarships granted. Silvia Ribeiro de Souza also thanks $\mathrm{CNPq}$ for the fellowship of research productivity provided (307281/2013-2).

\section{Literature cited}

Arakaki, S., Mantovani, W. 1998. Caracterização do clima e da vegetação do remanescente florestal no Planalto Paulistano (SP). In: Anais do IV Simpósio de ecossistemas brasileiros, São Paulo, pp. 25-36.

Arey, J., Winer, A., Atkison, R., Aschmann, S.M., Long, W.D., Morrison, C.L. 1991. The emission of (z)-3hexen-1-ol, (z)-3-hexenylacetate and other oxygenated hydrocarbons from agricultural plant species. Atmospheric Environment, v. 25, pp. 1063-1075.

Arimura, G. I, Matsui, K, Takabayashi, J. 2009. Chemical and molecular ecology of herbivore-induced plant volatiles: proximate factors and their ultimate functions. Plant and Cell Physiology, v. 5, p. 911-923.

Baier, M., Kandlbinder, A., Golldack, D., Dietz, K. J. 2005. Oxidative stress and ozone: perception, signaling and response. Plant, Cell \& Environment, v. 8, pp. 1012-1020.

Bartram, S., Jux, A., Gleixner, G., Boland, W. 2006. Dynamic pathway allocation in early terpenoid biosynthesis of stress-induced lima bean leaves. Phytochemistry, v. 67, pp. 1661-1672.
Bourtsoukidis, E., Bonn, B., Dittmann, A., Hakola, H., Hellén, H., Jacobi, S. 2012. Ozone stress as a driving force of sesquiterpene emissions: a suggested parameterisation. Biogeosciences, v. 11, pp. 4337-4352.

Cardoso-Gustavson, P., Bolsoni, P.V., Oliveira, D.P., Guaratini, M.T.G.,Aidar, M.P.M., Marabesi, M.A., Alves, S., Souza, S.R. 2014. Ozone-Induced Responses in Croton floribundus Spreng. (Euphorbiaceae): Metabolic Cross-Talk between Volatile Organic Compounds and Calcium Oxalate Crystal Formation. PLoS ONE, v. 9, pp. 1-10.

Carvalho, L.R., Vasconcellos, P.C., Mantovani, W., Pool, C.S., Pisani, S.O. 2005. Measurements of biogenic hydrocarbon and carbonyl compounds emitted by trees from temperate warm Atlantic rainforest, Brazil. Journal of Environmental Monitoring, v. 7, pp. 493-499.

CETESB (Companhia Ambiental do Estado de São Paulo). 2012. Relatório de qualidade do ar 2012, http:// cetesb.sp.gov.br/ar/publicacoes-relatorios/ (acesso em 02-II-2011).

CETESB (Companhia Ambiental do Estado de São Paulo). 2013 Relatório de qualidade do ar 2013. Available in http://cetesb.sp.gov.br/ar/publicacoesrelatorios/ (acesso em 02-II-2011).

Ciccioli, P. 1993. Chemistry and analysis of volatile organic compounds in the environment. Blackie Academic \& Professional, London, pp. 92.

Fehsenfeld, F., Calvert, J., Fall, R., Goldan, P., Guenther, A., Hewitt, T.N., Lamb, B., Lui, S., Trainer, M., Westberg, H., Zimmermam, P. 1992. Emissions of volatile organic compounds from vegetation and the implications for atmospheric chemistry. Global Biogeochemical Cycles, v. 6, pp. 389-430.

Guenther, A. 1997. Seasonal and special variation in natural volatile organic compounds emission Ecological Application, v. 11, pp. 221-235.

Guenther, A., Hewitt, C.N., Erickson, D., Fall, R., Geron, C., Graedel, T., Harley, P., Klingr, L., Lerdau, M., Mackay, W.A., Pierce, T., Scholes, B., Steinbrecher, R., Tallaraju, R., Taylor, J., Zimmerman, P. 1995. A global model of nature volatile organic compound emissions. Journal of Geophysical Research, v. 100, pp. 8873-889.

Kesselmeier, J., Staudt, M. 1999. Biogenic volatile compounds (VOC): an overview on emission, physiology and ecologic. Journal of Atmospheric Chemistry, v. 33, pp. 23-88.

Krupa, S.V., Manning, W.J. 1998. Atmospheric ozone: formation and effects on vegetation. Environmental Pollution, v. 50, pp. 101-137.

Leme, C.L.D. 1994. Anatomia Comparada do lenho do caule, raiz e ramo de algumas espécies de Euphorbiaceae da Mata Atlântica. Dissertação de Mestrado, Universidade de São Paulo, São Paulo.

Loreto, F., Velikova, V. 2001. Isoprene produced by leaves protects the photosynthetic apparatus against ozone damage, quenches ozone products, and reduces lipid peroxidation of cellular membranes. Plant Physiology, v. 127, pp. $1781-1787$. 
Loreto, F., Barta, G., Brilli, F., Nogues, I. 2006. On the induction of volatile organic compound emissions by plants as consequence of wounding or fluctuations of light and temperature. Plant Cell Environment, v. 29, pp. 1820-1828.

Loreto, F., Schnitzler, J.P. 2010. Abiotic stresses and induced BVOCs. Trends in Plant Science, v. 3, pp. 154-166.

Meira Junior, M.S., Pereira, I.M., Machado, E.L.M., Mota, S.L.L., Oton, T.J.O. 2015. Espécies potenciais para recuperação de áreas de floresta estacional semidecidual com exploração de minério de ferro na serra do espinhaço. Bioscience Journal, v. 31, n. 1, pp. 283-295.

Monson, R.K. 1992. Relationship among isoprene emission rate, photosynthesis, and isoprene synthase activity as influenced by temperature. Plant Physiology, v. 98, pp. 1175-1180.

Niinemets, U., Arneth, A. Kuhn, U., Monson, R.K., Peñuelas, J., Staudt, S. 2010. The emission factor of volatile isoprenoids: stress, acclimation, and developmental responses. Biogeosciences, v. 7, pp. 2203-222.

Orlando, J.P., Alvim, D.S., Yamazaki, A., Corrêa, S.M., Gatti, L.V. 2010. Ozone precursors for the São Paulo Metropolitan Area. Science of the Total Environment, v. 7, pp. 1612-1620.
Owen, S.M., Boissard, C., Hagenlocher, B., Hewitt, N.C. 1998. Field studies of isoprene emissions from vegetation in the Northwest Mediterranean region. Journal of Geophysical Research, v. 25, pp. 499-511.

Peñuelas, J., Llusia, J., Gimeno, B.S. 1999. Effects of ozone concentrations on biogenic volatile organic compounds emission in the Mediterranean region. Environmental Pollution, v. 105, pp. 15-18.

Schirmer, W.N., Quadros, M.E. 2010. Compostos orgânicos voláteis biogênicos emitidos a partir de vegetação e seu papel no ozônio troposférico urbano. REVSBAU, v. 5, pp. 25-42.

Sienfeld, J. H., Pandis, S. N. 1998. Atmospheric Chemistry and physics: from air pollution to climate change. John Willy \& Sons, New York. pp. 235.

Souza, S. R., Vasconcellos, P.C., Mantovani, W., Carvalho, L. 2002. Emissão por folhas de Ficusbenjamina L. (Moraceae) de compostos orgânicos voláteis oxigenados. Revista Brasileira de Botânica, v. 25, pp. 413-418.

Tingey, D.T., Turner, D.P., Weber, J.A. 1991. In: E. Sharkey, H. Holland, H. Mooney (ed.). Factor controlling the emissions of monoterpenes organic compounds. In trace gas emissions by plants. Academic Press, San Diego, pp. 93-13.

Ziroldo, B.D. 2007. Estrutura genética em diferentes populações de 324 Croton floribundus Spreng. de diferentes fragmentos de mata. Dissertação de Mestrado, Universidade Estadual de Londrina, Londrina. 